\title{
Effects of Magnetic Field on Corrosion Behaviour of X100 Pipeline Steel in Simulated Soil Solution Containing Sulphate- Reducing Bacteria
}

\author{
Gao Zhenbang ${ }^{1,2}$, Wang Dan ${ }^{1,2, *}$, Jiang Jintao ${ }^{3}$, He Jianyu ${ }^{1,2}$, Wang Yue ${ }^{1,2}$, Xie Fei ${ }^{1,2, *}$ \\ ${ }^{1}$ College of Petroleum Engineering, Liaoning Shihua University, Fushun 113001, China \\ ${ }^{2}$ Key Laboratory of Oil and Gas Storage and Transportation Technology in Liaoning Province, Fushun \\ 113001, China \\ ${ }^{3}$ Liaohe Oilfield Oil and Gas Gathering and Transmission Company, Panjin, 124000, China \\ *E-mail: wd841015@163.com (Wang Dan); xiefei0413@163.com (Xie Fei)
}

Received: 13 September 2021 / Accepted: 18 October 2021 / Published: 10 November 2021

The magnetic field (MF) is often utilized in engineering as a means of removing microbial bacteria. The effects of an MF on the electrochemical corrosion behaviour of X100 pipeline steel caused by sulphatereducing bacteria (SRB) were investigated by electrochemical tests and scanning electron microscopy (SEM). The results showed that the MF inhibited the growth and activity of SRB, and the corrosion rate of X100 steel initially decreased and then increased with increasing MF strength. The lowest corrosion rate of X100 steel was observed under a 5-mT MF. These results are also attributed to the effect of the MF on the mass transfer of the corrosive medium..

Keywords: Magnetic field; Sulphate-reducing bacteria; X100 steel; Electrochemical corrosion; Mass transfer

\section{$\underline{\text { FULL TEXT }}$}

(C) 2021 The Authors. Published by ESG (www.electrochemsci.org). This article is an open access article distributed under the terms and conditions of the Creative Commons Attribution license (http://creativecommons.org/licenses/by/4.0/). 